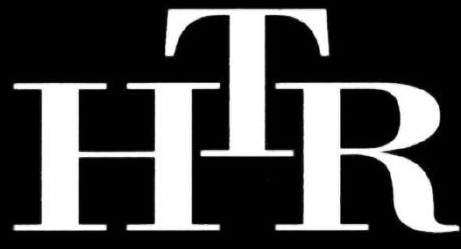

\title{
Harvard
}

Theological

Review

85:3

J U L Y 19992

ISSN $0017-8160$ 


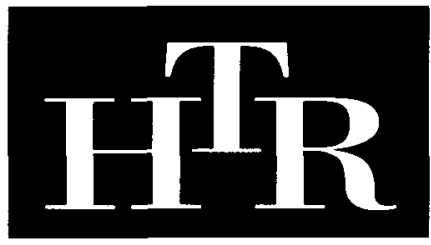

\section{Harvard Theological Review 85:3}

ISSUED. OUARTERLY BY THE FACULTY OF DIVINITY IN HARVARD UNIVERSITY

The Harvard Theological Review is maintained on the foundation established under the will of Mildred Everett, daughter of Charles Carroll Everett, Bussey Professor of Theology in Harvard University, 1869-1900, and Dean of the Faculty of Divinity, 1878-1900. The scope of the Review embraces theology, ethics, the history and philosophy of religion, and cognate subjects. It aims to publish investigations, discussions, and reviews that contribute to the enlargement of knowledge or the advance of thought.

\section{EDITOR}

\section{Helmut Koester}

EDITORIAL BOARD

Bernadette Brooten, John B. Carmen, David D. Hall, Jon D. Levenson, and Ronald F. Thiemann

ASSOCIATE EDITORS

Members of the Faculty of Divinity

MANAGING EDITOR

\section{Tamar Duke-Cohan}

EDITORIAL ASSISTANTS

\section{Ellen B. Aitken, Christopher Elwood, Laura Nasrallah, and Tyler T. Roberts}

CONSULTANTS

Phyllis Bird, Albert Blackwell, Stephen Boyd, C. Mackenzie Brown, John Collins, Stephen N. Dunning, Timothy George, Jay Harris, Rosemary Hale, Susan Ashbrook Harvey, Bill King, A. Thomas Kraabel, Bentley Layton, Robin Lovin, Patrick D. Miller, Stephen Prothero, Wayne Proudfoot, Roger Reynolds, Philip Sellew, Bernard Septimus, Mark Taylor, and Ernest Wallwork

Manuscripts and communications on editorial matters should be directed to the attention of the managing editor at the following address: Harvard Theological Review, Harvard Divinity School, 45 Francis Avenue, Cambridge, MA 02138. Questions related to subscriptions should be directed to the attention of the subscription coordinator, at the same address. "Instructions to Contributors" are available in HTR 80:2 (April 1987) 243-60.

The subscription rate for individuals is $\$ 25$ per year and for institutions $\$ 45$ per year (add $\$ 5.00$ per year for mailing outside the United States), payable in advance or on receipt of invoice. For student rates, direct inquiries to the subscription coordinator.

Back issues of vols. 1 (1908) through 64 (1971) are available in print from Kraus-Thompson Organization, Route 100 , Millwood, NY 10546; (914) 762-2200. For more recent issues and vols. 1 (1908) through 69 (1976) in microfiche, contact the subscription coordinator at our Cambridge address.

Typeset in the Harvard Theological Review Offices

Printed and Bound at Cushing-Malloy, Inc., Ann Arbor, Michigan

(C) Copyright 1992 by the President and Fellows of Harvard College 